\title{
BIBLIOTEKA WYDZIALU PRAWA I ADMINISTRACJI UNIWERSYTETU SZCZECIŃSKIEGO
}

Uniwersytet Szczeciński został utworzony w 1985 roku. W jego skład weszły dwie jednostki organizacyjne: Wyższa Szkoła Pedagogiczna w Szczecinie oraz Wydział Ekonomiczny Politechniki Szczecińskiej. W Wyższej Szkole Pedagogicznej działało Studium Administracyjne, na bazie którego powstał Instytut Prawa i Administracji Uniwersytetu Szczecińskiego. Po pewnym czasie Instytut ten przekształcony został w Wydział Prawa i Administracji. W latach 1989-1996 byłem dziekanem tego Wydziału. Natomiast wcześniej pełniłem funkcję zastępcy kierownika Instytutu.

$\mathrm{Na}$ początku było bardzo trudno. Instytut Prawa i Administracji nie miał bowiem ani swojej siedziby, ani stałej kadry naukowej, ani rozwiniętej odpowiednio biblioteki. Zajęcia dydaktyczne prowadzone były w baraku przy ul. Tarczyńskiego, należącym do Wydziału Humanistycznego. Nauczaniem studentów zajmowali się głównie przedstawiciele praktyki prawniczej (sędziowie, radcowie prawni, adwokaci). Biblioteka nie zaspokajała potrzeb pracowników i studentów, byli więc zmuszeni do korzystania z bibliotek innych ośrodków naukowych.

Warunki lokalowe Instytutu Prawa i Administracji uległy pewnej poprawie dopiero wtedy, gdy został on przeniesiony do nowo wybudowanego baraku przy ul. Łukasińskiego. Jednakże istotna zmiana w tym zakresie nastąpiła dopiero po uzyskaniu przez Wydział Prawa i Administracji budynku przy ul. Narutowicza, w którym wcześniej mieściły się koszary wojskowe. Poprawiły się w sposób odczuwalny warunku studiowania i pracy, biblioteka zaś otrzymała odpowiednią siedzibę, ulokowana została mianowicie na parterze budynku oraz w jego piwnicach. 
W miarę upływu czasu zmieniała się także sytuacja kadrowa Wydziału Prawa i Administracji. Przedstawiciele praktyki prawniczej, którzy prowadzili zajęcia dydaktyczne, zastępowani byli sukcesywnie profesorami dojeżdżającymi z innych ośrodków naukowych, w tym zwłaszcza z Poznania i Wrocławia. Po kilku latach Wydział Prawa i Administracji stał się w pełni samodzielnym ośrodkiem naukowym, mającym zarówno uprawnienia do nadawania stopnia doktora nauk prawnych, jak i doktora habilitowanego.

W utrzymaniu odpowiedniego poziomu pracy naukowej i dydaktycznej istotną rolę odegrała biblioteka wydziałowa. Jej księgozbiór gromadzony był w dwojaki sposób. Książki wydane w latach poprzedzających powstanie Wydziału Prawa i Administracji pochodziły z darów innych instytucji naukowych oraz z darów osób fizycznych (sędziów, adwokatów, pracowników uczelni). Na przykład prof. dr hab. Ludwik Bar z Instytutu Nauk Prawnych PAN podarował Wydziałowi Prawa w Szczecinie całą swoją bibliotekę prawniczą. Nowe wydawnictwa zaś nabywane były przez bibliotekę ze środków finansowych Uniwersytetu. Obecnie Wydział Prawa i Administracji ma już bogate zbiory i dobrze wyposażoną w sprzęt elektroniczny czytelnię. Ze zbiorów tych korzystają nie tylko studenci i pracownicy Wydziału, lecz także osoby postronne.

Znakomity rozwój biblioteki wydziałowej jest przede wszystkim dziełem jej byłych i obecnych pracowników, którym należą się słowa uznania - w szczególności zaś Danucie Rejmer, przez wiele lat dzielnie kierującej biblioteką i dbającej o jej rozwój. 